\title{
Performance Evaluation of Water Application Attachment in Seed Drill for Mungbean (Vigna radiate L) Crop in Dryland
}

\author{
Kanishk Verma ${ }^{1}$, Vijaya Rani ${ }^{2}$, Anil Kumar ${ }^{2}$, Nitin Karwasra ${ }^{1}$, \\ Narender $^{3}$ and S. Mukesh ${ }^{2}$ \\ ${ }^{1}$ Department of Farm Machinery and Power Engineering, COAE\&T, PAU, Ludhiana, India \\ ${ }^{2}$ Department of Farm Machinery and Power Engineering, CCS Haryana Agricultural \\ University, Hisar-125004, India \\ ${ }^{3}$ Department of Farm Machinery and Power Engineering, COAE\&T, JNKVV, Jabalpur, India \\ *Corresponding author
}

\section{A B S T R A C T}

\begin{tabular}{|c|}
\hline Keywords \\
\hline $\begin{array}{l}\text { Water application } \\
\text { attachment, Seed } \\
\text { drill, Field } \\
\text { efficiency, Field } \\
\text { capacity, Seed } \\
\text { emergence, Yield }\end{array}$ \\
\hline Article Info \\
\hline $\begin{array}{l}\text { Accepted: } \\
20 \text { December } 2017 \\
\text { Available Online: } \\
\text { 10 January } 2018\end{array}$ \\
\hline
\end{tabular}

Keywords

Water application attachment, Seed drill, Field efficiency, Field capacity, Seed emergence, Yield

\section{Introduction}

The south western szone of Haryana has 4.9 lac hectare dry land area. Mungbean (Vigna radiata $L$ ) is a short season summer growing legume grown predominantly under dryland conditions. Due to the erratic nature of summer rains and variation in stored moisture of soil at time of sowing, the crop is exposed to severity of water deficit which results in variability in grain yield, nitrogen accumulation and grain quality. Mungbean thrive best under the hot and humid climate of subtropical plains and do well on all types of soil, but light sandy loam to heavy clay is ideal soils for moong cultivation. Land is prepared with 1-2 ploughing with desi plough and disc harrow and each ploughing is followed by planking to get desired tilth. Seed rate required is 15 to $20 \mathrm{~kg}$ per ha. Kharif moong crop is sown with onset of monsoon upto $15^{\text {th }}$ July.

Sowing time is one of the major non-monetary input affecting the growth and yield of the crop. It affects the duration of vegetative, 
reproductive and maturity periods. Early sown mungbean has higher seed than where crop sown late. Early sown mungbean produced better results in terms of growth, yield and its contributing characters also the late sowing results in poor yield and low quality of seeds. Sowing dates also affects the height of plant, pods/plant, seeds/pod and 1000-seeds weight. Maximum plant height $79 \mathrm{~cm}$ was recorded when the crop was sown on $5^{\text {th }}$ July, followed by $15^{\text {th }}$ July sown crop with $62 \mathrm{~cm}$ and further decrease was noted on latter sowing dates. Pods per plant is an important yield component and contributes toward the grain yield. Results revealed that maximum number of pods per plant (18.3) was observed from $5^{\text {th }}$ July sown crop, followed by $15^{\text {th }}$ July that produced less (15.4) pods per plant similarly the seeds per pod also have better results in earlier sowing (Khan and Soomro, 2003).

Generally during kharif mungbean crop does not require any irrigation, but in case of failure of rains, the crop should be irrigated. In case of heavy rains, water should be drained off from the field, otherwise it will damage the crop. In dryland area sowing is done after the $1^{\text {st }}$ rain so that the soil conserves the appropriate moisture required for the seed germination. But, if $1^{\text {st }}$ rain of season is delayed it tends to the late sowing which results in bad affects on crop future and if crop sown on time before the $1^{\text {st }}$ rain than due to lack of required soil moisture seeds will not germinate. This is a big problem in the dryland area which made us to think that still there is lack of technology for facing such conditions.. For sowing of crop on time and to generate the required soil moisture for the proper germination of seeds if the rain is delayed, the performance of water application attachment on seed drill was evaluated. This will help farmer to sow crop on time and generates proper soil moisture for seed germination which help to increase the production.

\section{Materials and Methods}

The machine was calibrated at workshop of Farm machinery and Power Engineering, COAE\&T, CCS HAU, Hisar and performance was evaluated at dryland Farm area of CCS HAU, Hisar.The machine consisted of a water tank of mild steel, capacity 115 liter. The water tank is mounted at rear side of seed drill on a mild steel frame. At the bottom of water tank one outlet is provided to which a throttle is attached for regulating the quantity of water. The throttle is connected to metal pipe of $2 \mathrm{~m}$ length and $1.5 \mathrm{~cm}$ diameter. This metal pipe is given six openings of diameter $1.5 \mathrm{~cm}$ at the distance of $40 \mathrm{~cm}$ in which rubber tubes of diameter $1.5 \mathrm{~cm}$ are attached and the other end of the rubber tubes are inserted in furrow opener just behind the seed tube. The rubber tubes are used because there are very flexible and can move in any direction and the length of rubber tubes is so selected that they can easily reach upto the furrow openers. The water regulation throttle is given at the bottom of the water tank. Detail specifications are shown in Table 1.1 and Fig. 1.1.

\section{Preliminary study}

Preliminary studies were carried by setting throttle at three positions for adjusting the water application rate. With $100 \%$ throttle open seed emergence obtained was $90 \%$ and water application rate was $40001 \mathrm{ha}^{-1}$, with $75 \%$ and $50 \%$ throttle open seed emergence of $89 \%$ and $88 \%$ was observed and water application rate was $3600 \mathrm{l} \mathrm{ha}^{-1}$ and $30001 \mathrm{ha}^{-1}$, respectively. The results were significant and the water application rate of $3000 \mathrm{l} \mathrm{ha}^{-1}$ was adjusted for further study to save water. The soil moisture content ranged from $0.82 \%$ $0.83 \%$ at a depth of $0-5 \mathrm{~cm}$ before rainfall. The moisture content increased to $12.28 \%$ $12.35 \%$ at the depth of $0-5 \mathrm{~cm}$ after sowing was done with WAASD on $2^{\text {nd }}$ July 2012 


\section{Machine operation}

The seed rate for water application attachment on seed drill was adjusted at $15 \mathrm{~kg} \mathrm{ha}^{-1}$. The row to row distance was adjusted at $40 \mathrm{~cm}$ and depth of sowing was $4 \mathrm{~cm}$. the performance of machine was evaluated for both dry andsoaked seeds of mungbean. Two operators are required for the field operation one to drive the tractor and second to operate the throttle valve behind the machine and management of seeds in seed box. Machine was operated at forwarding speed of $3.6 \mathrm{~km} \mathrm{~h}^{-1}$ with field capacity of 0.47 ha h-1 and $73 \%$ field efficiency. Fuel consumption was found 3.2 $\mathrm{lh}^{-1}$ and draft observed was $335 \mathrm{kgf}$.

\section{Field test}

Sowing was done on $2^{\text {nd }}$ July 2012. There is no rainfall before the date of sowing so the moisture content observed was very low as mentioned above. Rainfall was came after 14 days of sowing $(16.5 \mathrm{~mm})$ then after break of one day $(10.2 \mathrm{~mm})$ and then after break of three days $(37.2 \mathrm{~mm})$. Seed emergence were recorded $83 \%$ after 7 days of sowing.

\section{Results and Discussion}

Seed emergence was found more for dry seeds (87\%) thansoaked seeds $(83 \%)$. Plant height was measured more for dry seeds $85.7 \mathrm{~cm}$ and for soaked seeds it was $83.8 \mathrm{~cm}$. There is no significant difference in number of pods per plant for dry seeds and soaked seeds it was counted 36. Length of pod measured $5.01 \mathrm{~cm}$ for dry seeds and $4.71 \mathrm{~cm}$ for soaked seeds. Test weight was found $35.13 \mathrm{~g}$ for dry seeds and $35.19 \mathrm{~g}$ for soaked seeds. Yield was found more for dry seeds $6.1 \mathrm{q} \mathrm{h}^{-1}$ and for soaked seeds $5.9 \mathrm{q} \mathrm{h}^{-1}$. The cost of operation was calculated Rs $288 \mathrm{~h}^{-1}$ for water application attachment on seed drill.The benefit cost ratio obtained by calculation was 2.23 for dry seed, 2.13 for soaked seed.Breakeven point calculated was 26.9 for water application attachment on seed drill. Payback period calculated was found 7 months for water application attachment on seed drill.

Table.1 Specifications of water application attachment on seed drill

\begin{tabular}{cc}
\hline Particulars & Specifications \\
\hline $\begin{array}{c}\text { Working width of machine } \\
(\mathrm{cm})\end{array}$ & 240 \\
$\begin{array}{c}\text { Overall dimensions of water } \\
\text { tank }(\mathrm{cm})\end{array}$ & $70 \times 30 \times 55$ \\
Tank capacity (liters) & 100 \\
Length of metal pipe $(\mathrm{cm})$ & 200 \\
Distance between opening & 40 \\
$(\mathrm{~cm})$ & 3 \\
Diameter of throttle $(\mathrm{cm})$ & 30 \\
Length of rubber pipe $(\mathrm{cm})$ & 1.5 \\
Diameter of rubber pipe $(\mathrm{cm})$ & Gravity flow \\
Water flow regulation &
\end{tabular}


Fig.1 Water application attachment on seed drill

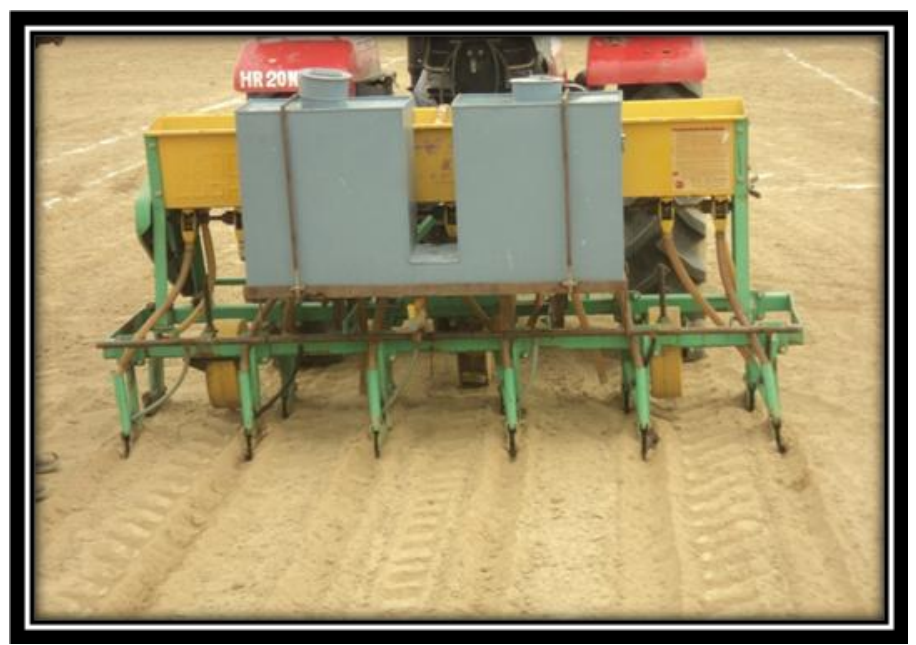

In conclusions, machine was capable for sowing timely if rainfall is delayed in dry land area. The water application rate of $30001 \mathrm{ha}^{-1}$ increased moisture content by $12 \%$. The effective field capacity of water application attachment on seed drill was $0.47 \mathrm{ha} \mathrm{h}^{-1}$ at average operating speed of $3.6 \mathrm{~km} \mathrm{~h}^{-1}$. The field efficiency was $73 \%$.Sowing depth was 4 cm by water application attachment on seed drill. Test weight was $0.5 \%$ more for soaked seeds than dry seeds. The machine may be recommended in the dryland area for timely sowing of crops, however for confirmation of results more testing is required.The water application attachment on seed drill may be tested in irrigated areas for different crops, such that one irrigation can be saved which is required to obtain optimum moisture content for sowing the crops.

\section{References}

Akmal, M., Shah, S. M., Asim, M. and Arif, M. 2011. Causes of yield reduction by delayed planting of hexaploid wheat in Pakistan. Pak. J. Bot. 43 (5): 25612568.

Kataria, D. P. 1984. Recent developments in farm machinery under dryland farming conditions at HAU. Paper presented in Refresher Training organized by the department of Agricultural Engineering for the Agricultural Engineerings working in teaching and research at Haryana Agricultural University, Hisar, 7-8 ${ }^{\text {th }}$ August, 1984.

Khan, R. and Soomro. 2003. Respose of mungbean Genotype to different dates of sowing in kharif season under rainfed condition. Asian journal of plant sciences. 4: 377-379

Malik, M. A., Saleem, M. F., Ali, A. and Ishaq, R. A. F. 2006. Effect of sowing dates and planting patterns on growth and yield of mungbean (Vignaradiata L.). J. Agric. Res. 44 (2): 139-148.

Ram, S. N. and Dixit, R. S. 2001. Growth, yield attributing parameters and quality of summer green gram as influenced by dates of sowing and phosporous. Indian J. Agric. Res. 35 (4): 275-277.

Rana, A. F., Javaid, I., Muhammad, A. A. and Haji, A. B. 2006.Effect of sowing dates and planting patterns on growth and yield of mungbean (VignaradiataL) cv.M-6. International 
Journal of Agriculture \&Biology. 08: 363-365.

Yadav, M. and Warri, A. S. 2009. Performance of summer planted mungbean in relation to irrigation and plant density. Indian J. Agron. 33 (1):
19-21.

Yarnia, M., Khorshidi, M. B. and Farajzadeh, D. 2010. Sowing dates and density evaluation of amaranth as a new crop. Journal of Food, Agriculture \& Environment.8 (2): 445-447.

\section{How to cite this article:}

Kanishk Verma, Vijaya Rani, Anil Kumar, Nitin Karwasra, Narender and Mukesh, S. 2018. Performance Evaluation of Water Application Attachment in Seed Drill for Mungbean (Vigna radiate L) Crop in Dryland. Int.J.Curr.Microbiol.App.Sci. 7(01): 2755-2759.

doi: https://doi.org/10.20546/ijcmas.2018.701.330 